



\title{
Diversity of the 2014 Iquique's foreshocks and aftershocks: clues about the complex rupture process of a Mw 8.1 earthquake
}

\author{
Sergio León-Ríos • Sergio Ruiz • \\ Andrei Maksymowicz • Felipe Leyton • \\ Amaya Fuenzalida • Raúl Madariaga
}

\begin{abstract}
We study the foreshocks and aftershocks of the 1 April 2014 Iquique earthquake of Mw 8.1. Most of these events were recorded by a large digital seismic network that included the Northern Chile permanent network and up to 26 temporary broadband digital stations. We relocated and computed moment tensors for 151 events of magnitude $\mathrm{Mw} \geq 4.5$. Most of the foreshocks and aftershocks of the Iquique earthquake are distributed to the southwest of the rupture zone. These events are located in a band of about $50 \mathrm{~km}$ from the trench, an area where few earthquakes occur elsewhere in Chile. Another important group of aftershocks is located above the plate interface, similar to those observed during the foreshock sequence. The depths of these events were constrained by regional moment
\end{abstract}

S. León Ríos $\cdot$ S. Ruiz $(\varangle) \cdot$ A. Maksymowicz Departamento de Geofísica, Facultad de Ciencias Físicas y Matemáticas, Universidad de Chile, Santiago, Chile e mail: sruiz@dgf.uchile.cl

F. Leyton

Centro Sismológico Nacional, Facultad de Ciencias Físicas y Matemáticas, Universidad de Chile, Santiago, Chile

A. Fuenzalida

School of Environmental Sciences, University of Liverpool, Liverpool, UK

R. Madariaga

Laboratoire de Geologie, UMR8538 CNRS Ecole Normale Superieure, Paris, France tensor (RMT) solutions obtained using the records of the dense broad band network. The majority of the foreshocks and aftershocks were associated to the interplate contact, with dip and strike angles in good agreement with the characteristics of horst and graben structures ( $>2000 \mathrm{~m}$ offset) typical of the oceanic Nazca Plate at the trench and in the outer rise region. We propose that the spatial distribution of foreshocks and aftershocks, and its seismological characteristics were strongly controlled by the rheological and tectonics conditions of the extreme erosive margin of Northern Chile.

Keywords Earthquake $\cdot$ Chile $\cdot$ Nazca Plate $\cdot$ Moment tensor. Erosive margin

\section{Introduction}

On 1 April 2014, a Mw 8.1 earthquake occurred offshore of the city of Iquique, located in the Tarapaca Region in Northern Chile. This region had been identified as a seismic gap because the last mega-earthquake took place on 9 May 1877 with a magnitude greater than Mw 8.5 (Kelleher 1972; Comte and Pardo 1991) (see Fig. 1a). Several events larger than seven occurred in this area since 1911 (Malgrange and Madariaga 1983; Comte and Pardo 1991; Pacheco and Sykes 1992; Ruegg et al. 1996; Engdahl and Villaseñor 2002; Peyrat et al. 2010). Inversions of geodetic data (interferometry and GPS) by Béjar-Pizarro et al. (2013) and Métois et al. (2013) found high values of interseismic 
coupling on the coastal region of Northern Chile anticipating the occurrence of a major earthquake in this zone. The 2014 Iquique earthquake filled the central region of the Northern Chile seismic gap (see Fig. 1).

The possible occurrence of a future mega-earthquake in Northern Chile led in 2006 to the deployment of a seismological network by the Integrated Plate boundary Observatory in Chile (IPOC) and the National Seismological Center (CSN) of the Universidad de Chile. After the beginning of the immediate precursors on 16 March 2004, these networks were supplemented by 26 temporary broadband stations, constituting a denser network that recorded the final seismic process leading to the 2014 Iquique earthquake and its aftershocks (Fig. 1a). The seismic sequence that ended in the Mw 8.1 event started several years earlier. Seismicity near Iquique started to increase when an event of Mw 6.3 occurred on 4 February 2008 south of Iquique. Since then, seismicity steadily increased until it reached a peak 2 weeks before the main shock (Ruiz et al. 2014; Schurr et al. 2014; Lay et al. 2014; Hayes et al. 2014) (see Fig. 1b). On 16 March 2014, the largest foreshock, an Mw 6.7 earthquake occurred within the overriding South American plate. The focal mechanism of this event was a reverse fault, with a strike direction at large angle with respect to the trench. After 16 March, the precursory seismicity migrated $50 \mathrm{~km}$ to the north where several $\mathrm{Mw} \sim 6.0$ reverse events

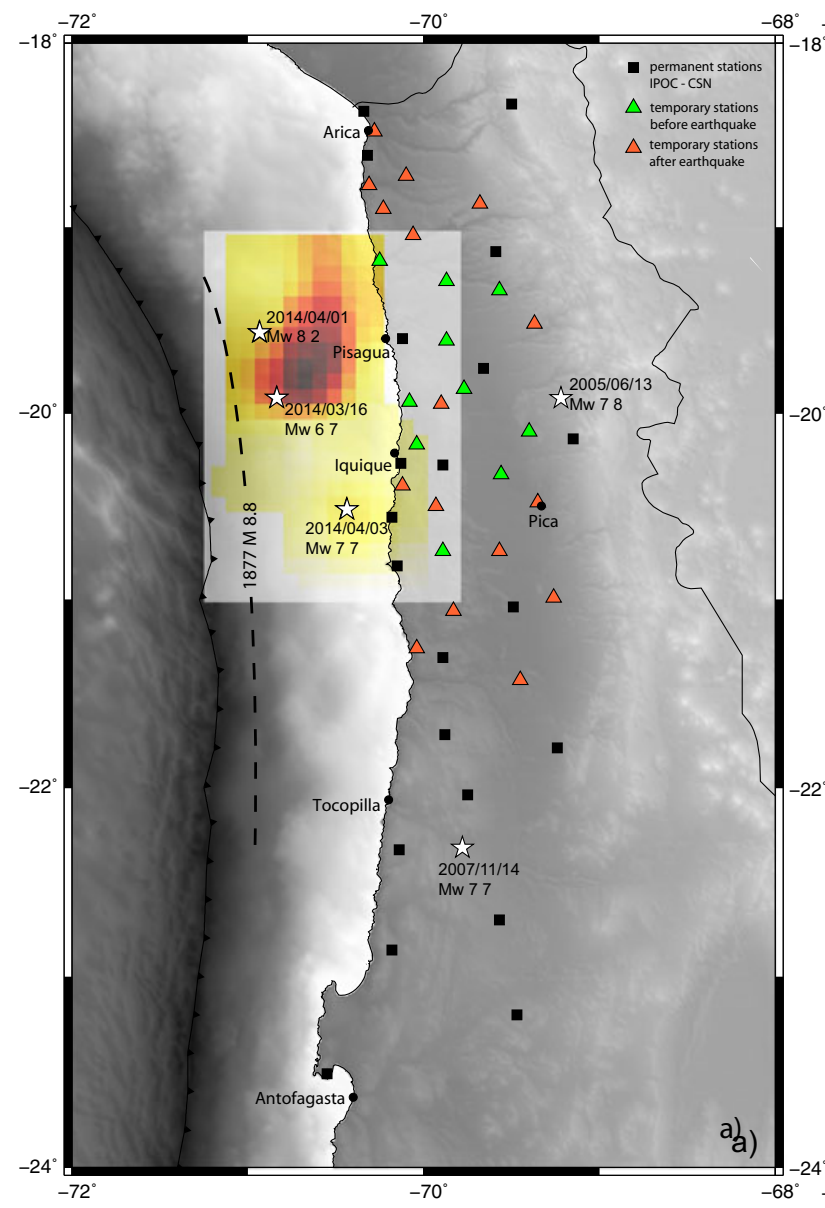

Fig. 1 Iquique Earthquake of 1 April 2014 in its context. On the left (a), the stars show the main foreshock of 16 March 2014, the main event of 1 April 2014, and its main aftershock of 3 April 2014. We also included the $2007 \mathrm{Mw} 7.7$ Tocopilla earthquake and the $2005 \mathrm{Mw} 7.8$ Tarapaca earthquake. Triangles show the broad band instruments available for the localization and RMT determination. Black squares are the IPOC network; green and

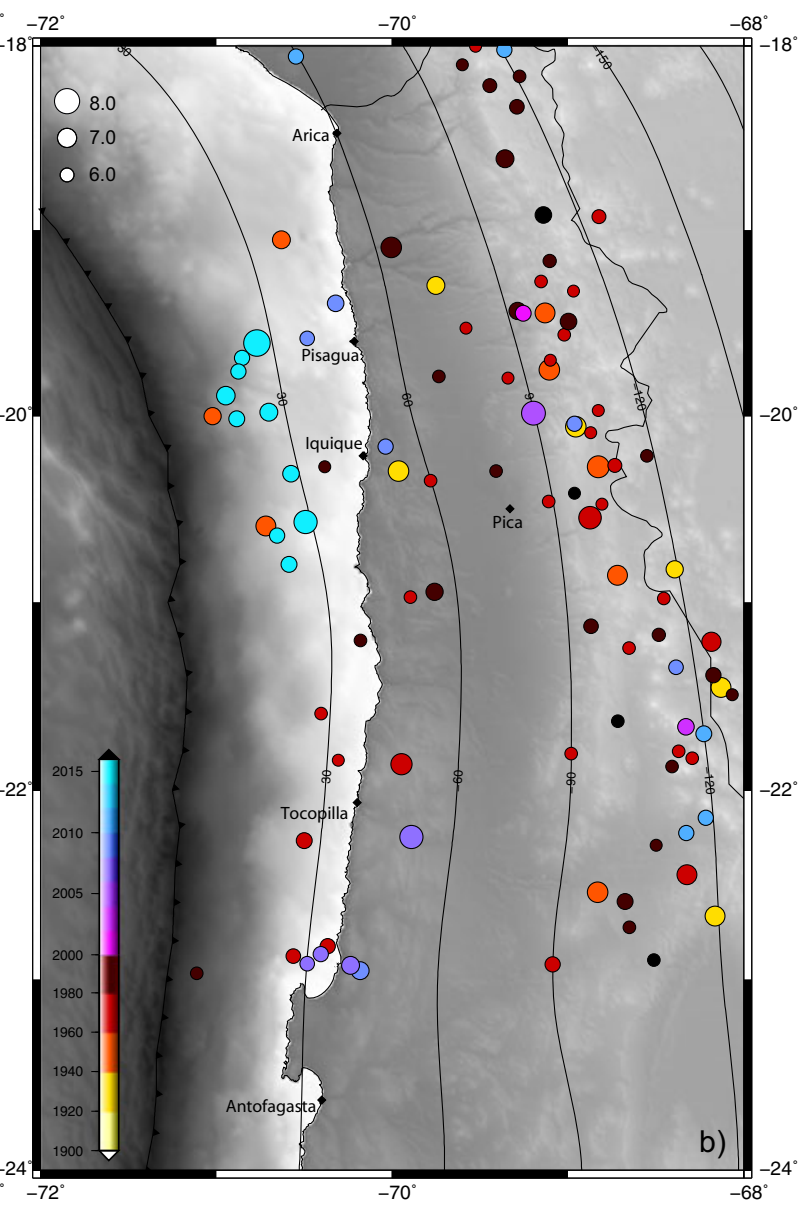

red triangles are the temporary stations available before and after the main event, respectively. Inset in the figure is the slip model for the 2014 Iquique earthquake and its main aftershock obtained by Ruiz et al. (2014) in order to show the rupture zone of the events. On the right (b) is the seismicity that preceded the main event of 1 April and its main aftershock of 3 April 2014. The events are color coded according to the date of occurrence 
occurred along the contact between the Nazca and South American plates. Finally, on 1 April, an estimated rupture zone of $100 \mathrm{~km} \times 50 \mathrm{~km}$ was broken by the main event of magnitude Mw 8.1 (Ruiz et al. 2014; Hayes et al. 2014; Schurr et al. 2014). The largest aftershock occurred on April 3, with magnitude Mw 7.6 in the deeper zone of the seismogenic contact, $100 \mathrm{~km}$ south of the hypocenter of the mainshock.

The seismicity on the plate interface from 2008 until the 1 April earthquake took place in a region that is usually considered with low background activity by many researchers (see, e.g., Scholz 1998). Lay et al. (2012) identified this area as type B, a region that produces low short period energy. Hubbard et al. (2015) discussed these classifications. It is thus important to study why a persistent zone of active seismicity developed at shallow depths in the Tarapaca Region of Northern Chile. Seismicity close to the trench of the subduction interface is rare in Chile, even if we take into consideration that until 2006, the seismic network was not good enough to detect smaller events in that area. A similar sequence of events occurred in July 1997 offshore of the Coquimbo Region of central Chile. Those events were followed 3 months later by the Mw 7.6 Punitaqui earthquake of 15 October 2007 (see Gardi et al. 2006). The 1997 event was an intermediate depth along slab compressional event, and the Coquimbo region was broken on 16 September 2016 by Illapel Mw 8.3 earthquake. It is important to understand why a long-term sequence of events occurred westward Iquique, close to the trench.

Another possible explanation for the origin of shallow seismicity is that the Iquique sequence took place in an erosive subduction margin (Ranero et al. 2006; Contreras Reyes et al. 2012). Northern Chile is characterized by a small frontal accretionary prism. In this context, the horst and graben structure ( $>2000 \mathrm{~m}$ offset) present in the first $50 \mathrm{~km}$ to the east of the trench of the oceanic Nazca Plate may control the diversity of events observed during foreshocks (Ruiz et al. 2014; Hayes et al. 2014; Schurr et al. 2014) and aftershocks. This behavior of the seismicity, with several types of events, has been observed in other large subduction earthquakes such as Maule 2010 (Agurto et al. 2012) and Tohoku 2011 (Zhan et al. 2012), but in these cases, the tectonic setting is quite different from that of the Northern Chile margin. For the Maule 2010 earthquake in Central South Chile, the events occurred under an accretionary margin that generates a large frontal prism that probably controls the updip limit of the interplate seismicity (Moscoso et al. 2011; Cubas et al. 2013; Maksymowicz et al. 2015). On the other hand, the Northeast Japanese area, where the Tohoku earthquake occurred has been recognized as an erosive margin (von Huene and Culotta 1989) with several heterogeneities in the subducting plate that could have been involved in the diversity of aftershocks observed in the deeper area of the rupture zone (Asano et al. 2011; Zhan et al. 2012).

In order to quantify this problem, we use the permanent and temporary network to relocate and estimate the focal mechanism of more than 150 events with magnitude larger than Mw 4.5. The high quality of the seismic and geodetic data obtained for this earthquake provided detailed information about the complex rupture process of this large subduction earthquake. These events include foreshocks and aftershocks that took place from 1 March to 31 July 2014. Then, we compare the distribution of foreshocks and aftershocks and discuss the tectonic context in which they occurred. Finally, we relate the seismicity to the rheological conditions of the Nazca and South American convergent margin.

\section{The Iquique earthquake and its precursors}

Northern Chile has been considered as a soon to break gap since the studies by Kelleher (1972); McCann et al. (1979), and Nishenko (1985). The last mega-earthquake occurred in this area on 9 May 1877 (see Fig. 1a). This event generated a large tsunami that flooded all the ports from Arica to Antofagasta and further south. More detailed studies of this event were provided by Montessus de Ballore (1912), Kausel (1986), and Comte and Pardo (1991). The region around Iquique has had a somewhat rare but non negligible seismicity in the twentieth century, including earthquakes in 1911 (M 7.1), 1933 (Mw 7.6), 1940 (mb 7.10) 1967 (Mw 7.4), 1995 (Mw 8.0), and 2007 (Mw 7.8). All these events are listed by Pacheco and Sykes (1992) and Urrutia and Lanza (1993), and appear in the centennial catalog of Engdahl and Villaseñor (2002) (see Fig. 1b). A few more magnitude 7 events before 1970 are listed by Comte and Pardo (1991). Activity at intermediate depth in Northern Chile was continuous with more than 30 events listed by Engdahl and Villaseñor (2002) (see Fig. 1b). In 2005, a large earthquake of Mw 7.7 took place under the town of Pica, located $115 \mathrm{~km}$ to the East of Iquique, in the forearc of the Andes mountain range 
in the Tarapaca Region (see Fig. 1b). This event usually referred to as the Tarapaca intermediate depth earthquake was well recorded by local GPS and far field seismic data (Peyrat et al. 2006).

In 2006, the IPOC network was installed in Northern Chile to survey the seismicity of the gap. On 14 November 2007, an earthquake of Mw 7.8 occurred near Tocopilla (Peyrat et al. 2010). A few months later, an event of magnitude 6.4 occurred near Iquique on 12 March 2008. Activity in this area increased steadily after that event, with events larger than M 6 in 2009, 2010, and 2014 (see Fig. 1b). After 2013 recurrent seismicity, sometimes swarms of small events occurred offshore Iquique, midway between the continent and the trench. More details about those early "precursors" can be found in the papers by Hayes et al. (2014), Kato and Nakagawa (2014), Ruiz et al. (2014), Schurr et al. (2014), Yagi et al. (2014), Meng et al. (2015). Although details of the activity vary among these different studies, it is clear that a vast area about $50 \mathrm{~km}$ wide located to the east of the trench was very active between 2008 and 1 April 2014 when the main Mw 8.1 Iquique event occurred.

\section{Data and methods}

The IPOC network in Northern Chile was created by a consortium of the Universities of Chile, the GFZ of Germany, and IPGP in France and was installed progressively starting from 2006. The network consists of 20 sites with broadband seismometers, accelerometers, and double frequency GPS receivers. After the large precursor of 16 March 2014, the IPOC network was extended by a temporary seismic network deployed by National Seismological Center (CSN). Installation started a few days before the mainshock and finished 2 weeks after the April 1, 2014, Iquique earthquake. Figure 1a shows the location of the broadband instruments used in this work and the time at which they were installed before or after the mainshock. All the stations shown in Fig. 1a recorded continuously in time with a sampling rate of $100 \mathrm{~Hz}$.

We use these data to locate and compute the centroid and depth of the moment tensor for the foreshocks and aftershocks. We initially created a catalog with events of magnitude greater than Ml 4.5 extracted from the CSN catalog, which for this zone and period is complete starting from magnitude Ml 4.0 (see Fig. 1 on
Electronic Supplementary Material). The events were relocated using the arrival time of $\mathrm{P}$ and $\mathrm{S}$ waves handpicked from all available traces with a visually good signal-to-noise ratio. The events were relocated using the Nonlinloc software (Lomax et al. 2000). We used the seismic velocity model proposed by Husen et al. (1999), who determined it for a region located about $200 \mathrm{~km}$ south of the present study area.

In Fig. 2, we compare the relocated events with the locations listed in the CSN catalogue for foreshocks and aftershocks. Figures 2 and 3 on Electronic Supplementary Material show the error bars for the relocated events. Our locations were improved with respect to those by CSN thanks to the much denser network of instruments which includes the temporary stations. As shown by Fuenzalida et al. (2013), locations determined using hand-picked arrivals are more accurate than those that use automatic picking because of the difficulty of automatic reading of head waves. However, the depths determined by phase picking have a high degree of uncertainty which can be improved by calculating the Regional Moment Tensor.

Once the earthquakes were relocated, we computed the regional moment tensor using the programs in Computer Programs in Seismology package (CPS) (Herrmann 2013). For this purpose, the epicenter location was fixed and we searched for the centroid depth and the best fitting double-couple source mechanism. This was done by a grid search: For each possible depth, we tested all possible double-couples and kept those that minimized the variance between observed and simulated traces. The final depth was the one that best fits the data. All available data were filtered between 0.02 and $0.06 \mathrm{~Hz}$, which, after several tests, proved to be the best frequency range to model events with magnitude between Mw 4.5 and 6.5. For the computation of synthetic seismograms, we used the same velocity model as for the localization (Husen et al. 1999) (see Figs. 3 and 4).

In order to validate our obtained moment tensors, we compared them with the solutions proposed by GFZ and USGS (see Figs. 4, 5, 6, 7, 8, 9, 10, 11, 12, and 13 on Electronic Supplementary Material). For the majority of the events, the MT depths present a better agreement with the slab model proposed by Hayes et al. (2012). The agreement is even better for the aftershocks, when the temporary network was in full operation. For the focal mechanisms, we obtained a fit better than 0.7 and good correlation between observed and synthetic waveforms. 


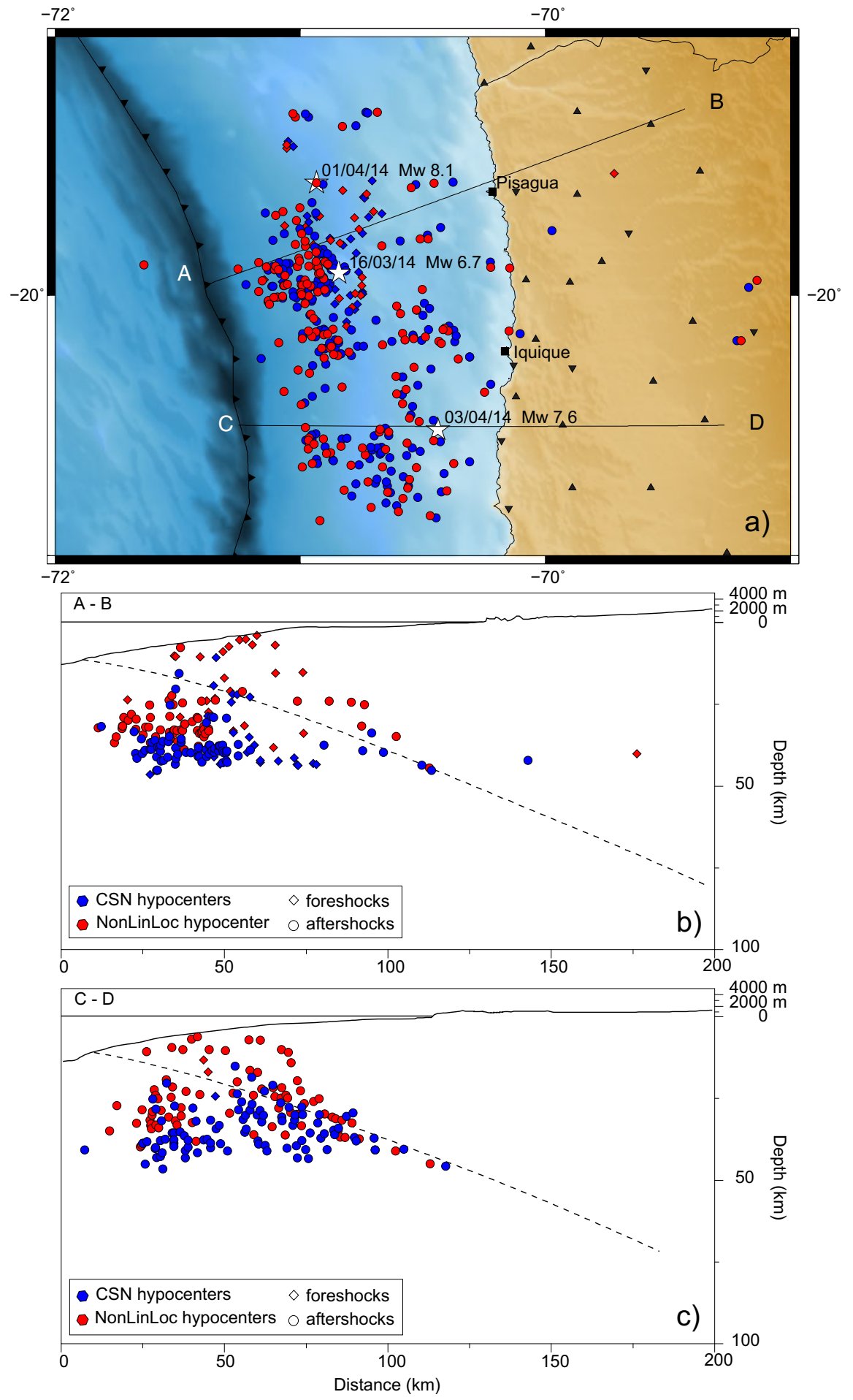

Fig. 2 Foreshocks and aftershocks of the 2014 Iquique earth quake. Foreshocks (diamonds) and aftershocks (circles) located using the NonLinLoc software (red symbols) compared with lo cations in the CSN catalogue (blue symbols). a Map view. The stars correspond to the epicenters of the main events of the Iquique

sequence. b, c Vertical profiles along lines $A B$ and $C D$ corre sponding to the in depth projection of the events. The segmented black line represents the seismogenic contact proposed by Hayes et al (2012) 
a)

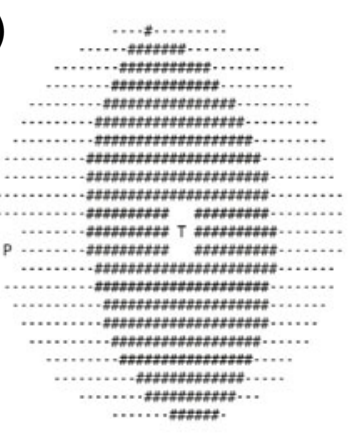

b)

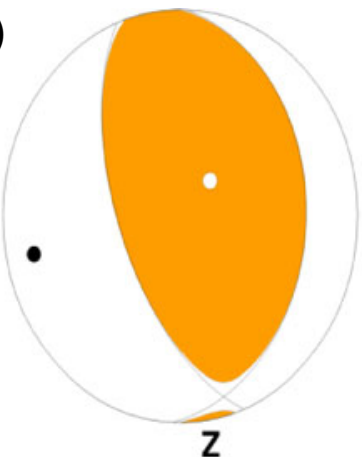

C) $\quad$ \#\#\#\#\#\#\#-...

….....\#\#\#\#\#\#\#\#\#-....

…….

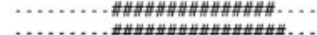

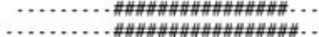

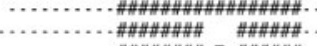

.

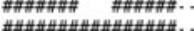

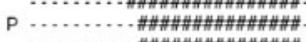

……......

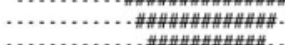

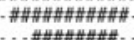

............... \#\#\#\#...

…….........

$\mathbf{R}$

T

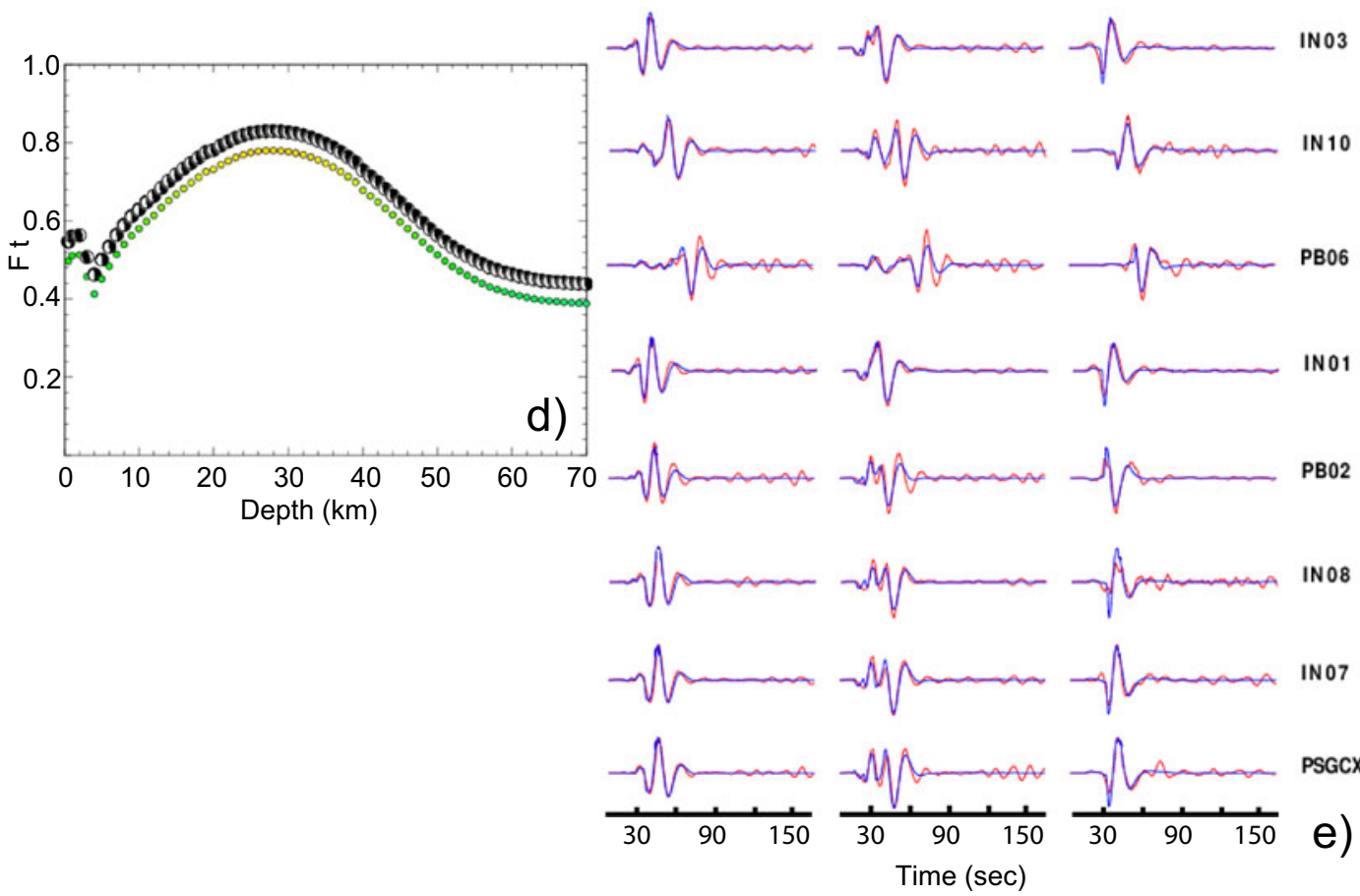

Fig. 3 Determination of moment tensor for a large aftershock of the 1 April 2014 earthquake. On the top, comparison between focal mechanisms solutions for the April 4, 2014 at 01:37:50 Mw 6.0 event, with hypocenter $20.61^{\circ} 70.74^{\circ}$ and $28 \mathrm{~km}$ depth, obtained by a this work, b USGS, and c GFZ. d Fit curve for the solution of this work. e Synthetic (blue) and observed (red) wave forms for the stations used in this event
Figures 3 and 4 show some examples of the fits between the synthetic and real data and the comparison of our proposed focal mechanism with GFZ and USGS solutions.

\section{Results}

In our database, we identified two kinds of events: interplate thrust events and crustal events located on the overriding South American plate. For the classification, we considered the centroid depth with respect to the plate interface defined by the model of Hayes et al. (2012) and the focal mechanism of each event. The proposed interplate thrust events have reverse focal mechanisms, with one focal plane close to the dip of subduction zone. It is possible, however, that the actual focal plane of some events was the steeper one if the event was located within the Nazca or South American plate.

The crustal events were identified mainly from their locations, above the seismogenic contact. In general, these events show reverse mechanism, with a rotated strike with respect to the trench. 
a)

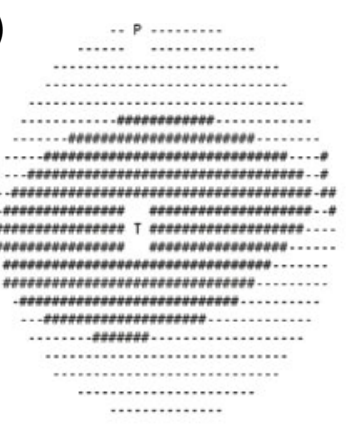

b)

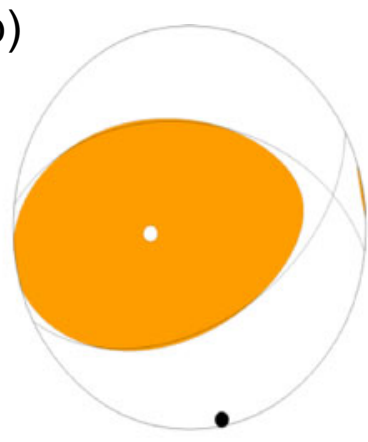

c)

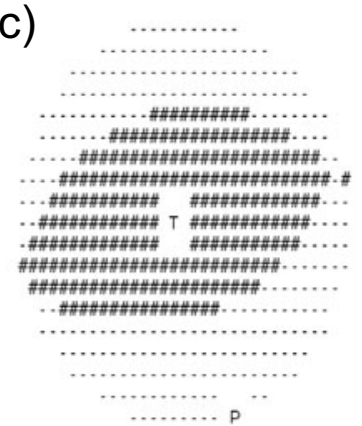

R T

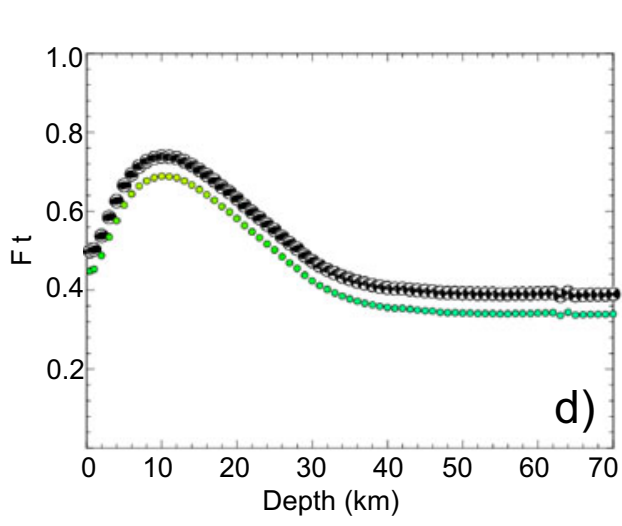

Z
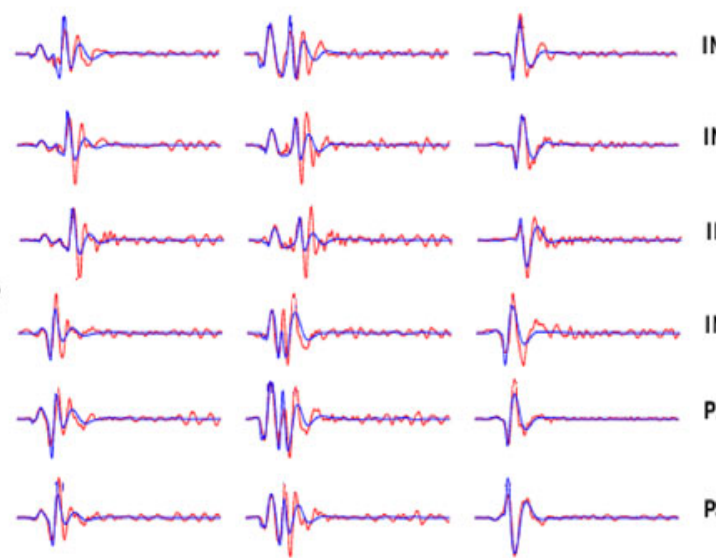
N01
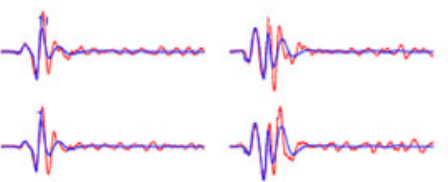<smiles>C1=CC=C1</smiles>
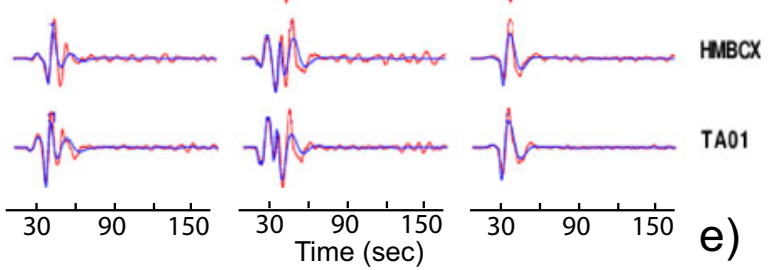

TA01

Fig. 4 Comparison between focal mechanism solutions for the aftershock of April 15, 2014 at 16:21:16. An event of Mw 5.0 with hypocenter $20.20^{\circ}, 70.87^{\circ}$, and $8 \mathrm{~km}$ depth. Mechanisms

Finally, a significant number of events have locations or focal mechanisms that do not permit us to clearly fit them in this classification. These events were left as unclassified and corresponds to normal or rotated interplate events. Figure 5 presents an example of observed data for the three kinds of events identified in this work.

Figure 6 shows the location and focal mechanism of the March foreshock sequence. This period is similar to that observed by Ruiz et al. (2014), who determined focal mechanisms for the foreshocks that occurred after 16 March 2014. Those events were computed using the permanent network plus a few temporary stations installed during this period (see Fig. 1a). For this time obtained by a this work, b USGS, and c GFZ. d Fit curve for the solution of this work. e Synthetic (blue) and observed (red) wave forms for the stations used in this event

span, we observe crustal (upper-plate) events and interplate events and some unclassified-rotated interplate, rare strike angle - earthquakes. The seismicity shows a time migration to the north for about $40 \mathrm{~km}$ from $20^{\circ} \mathrm{S}$ to $20.4^{\circ} \mathrm{S}$, toward the location of the epicenter of the Mw 8.1 main event (Ruiz et al. 2014). The strike angle of these events is mainly oriented northwest to southeast for the interplate events, with a more diverse orientation for the other events, as shown in the inset of Fig. 6a. An interesting feature observed in the foreshock distribution is that the dip angle of the interplate seismicity is larger than the dip of the subducted slab. This high angle of rupture is clearly observed in the shallower events (see Fig. 6b). 

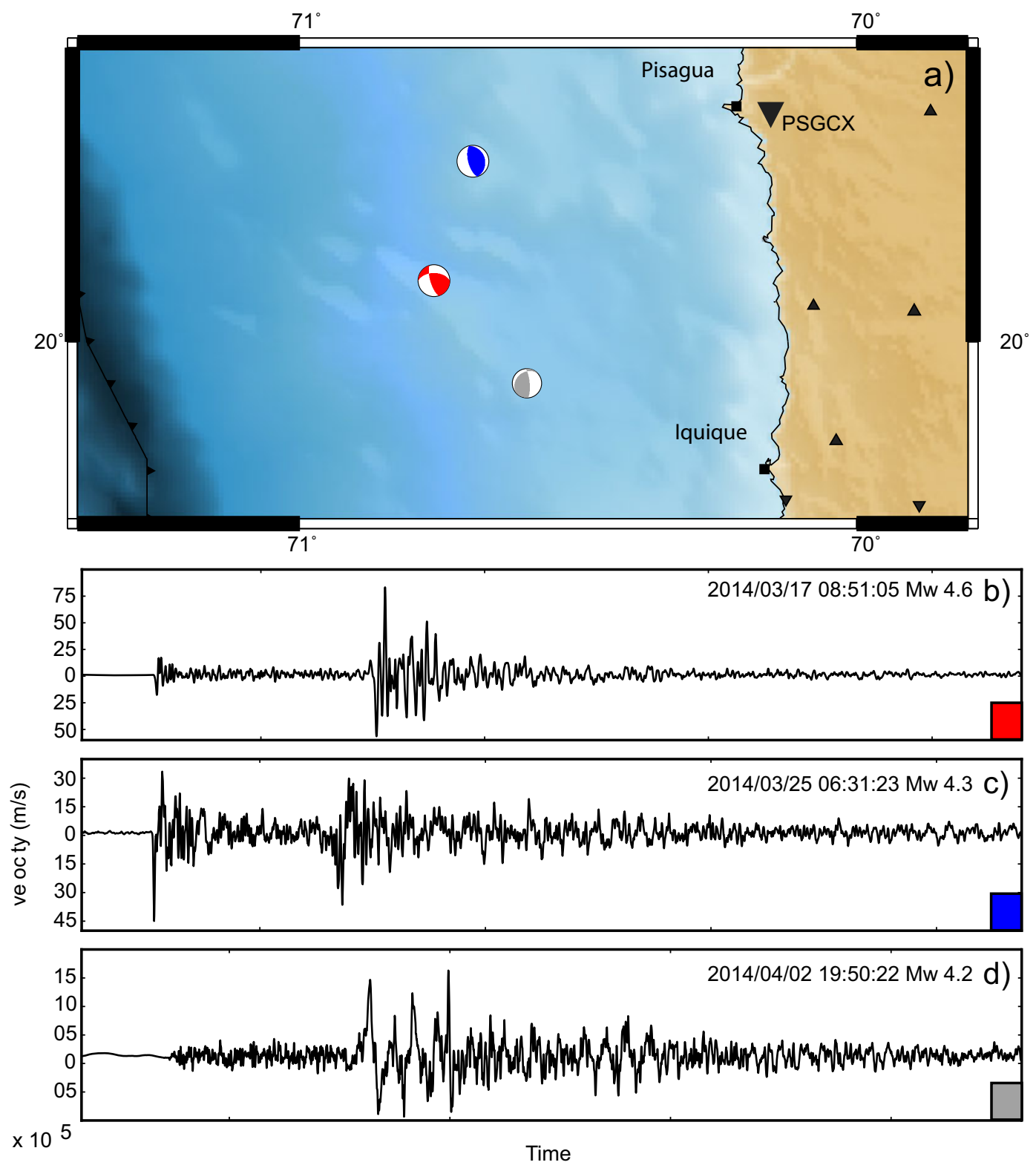

Fig. 5 Three events in the foreshock and aftershock series of the 1 April 2014 Iquique earthquake. a Map view of three selected events. b d Observed data for the PSGCX station for an intraslab

(red), an interplate (blue), and an unclassified (gray) event, respectively

Figure 7 shows the location and focal mechanism of the aftershocks from April 1 to July 31, 2014. The aftershock sequence does not present a clear migration as was observed during the foreshocks (Ruiz et al. 2014). We observe fewer crustal events with magnitude greater than $\mathrm{Mw} 4.5$ in comparison with the precursory events. We identified only five crustal events, four of them located outside of the foreshock area. The aftershocks show a clear concentration of events with

magnitude greater than $\mathrm{Mw} 4.5$ close to the trench. Most of these events are located in the first $50 \mathrm{~km}$ from the trench to the coast, in good agreement with the proposed depth of the slab geometry, as shown in Fig. 7b. Similar to the observed tendency in the foreshocks, the strike angle of the interplate events is mainly oriented northwest to southeast, while the other events present a more diverse orientation (see inset in Fig. 7a). Moreover, as with the foreshocks, the dip of the 


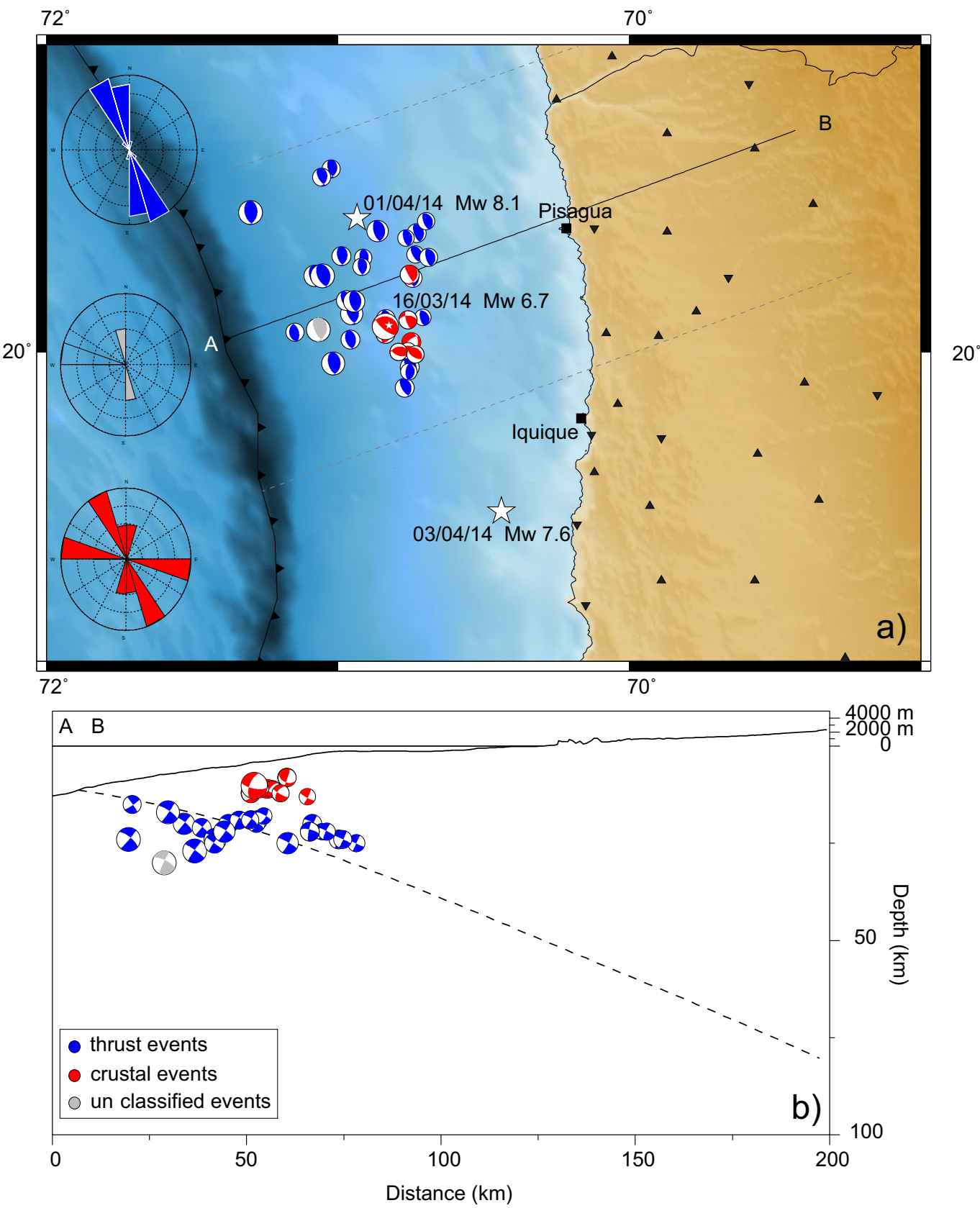

Fig. 6 Foreshocks with magnitude greater than Mw 4.5 of the 2014 Iquique earthquake. We interpret the blue focal mechanism as interplate events, red focal mechanism as crustal events inside the upper plate, and the gray focal mechanism as events we could not classify. a Map view of foreshocks. The stars correspond to the epicenters of the main events of the Iquique sequence, and the gray segmented line shows the selection width in the $A B$ profile

presented in Fig. 1b. The inset correspond to the strike angle, and the color is related with each type of event. b Profile showing the distribution as a function of depth of the foreshocks, the segmented line correspond to seismogenic zone proposed by Hayes et al. (2012). The focal mechanism of the Mw 6.7 event is that proposed by Ruiz et al. (2014)

interplate aftershocks is steeper than the seismogenic contact; with angles between $10^{\circ}$ and $50^{\circ}$, this feature

becomes even more evident for the events located $\sim 50 \mathrm{~km}$ landward from the trench (see Fig. 7a, b). 
Fig. 7 Aftershocks of the 2014 Iquique earthquake with magnitude greater than $\mathrm{Mw} 45$. Similar to Fig. 6, we interpret the blue focal mechanisms as interplate events, red focal mechanism as crustal events, and the gray focal mechanism as events we could not classify. a Map view of the aftershocks. The stars correspond to the epicenters of the main events of the Iquique sequence, and the gray segmented lines show the selection width for the $A B$ and $B C$ profiles projected in Fig. 2b, c. The inset corresponds to the strike angle, and the color is related with each type of event. b, $\mathbf{c}$ Profiles showing the distribution as a function of depth of the aftershocks, the segmented line, correspond to the seismogenic zone proposed by Hayes et al. (2012)
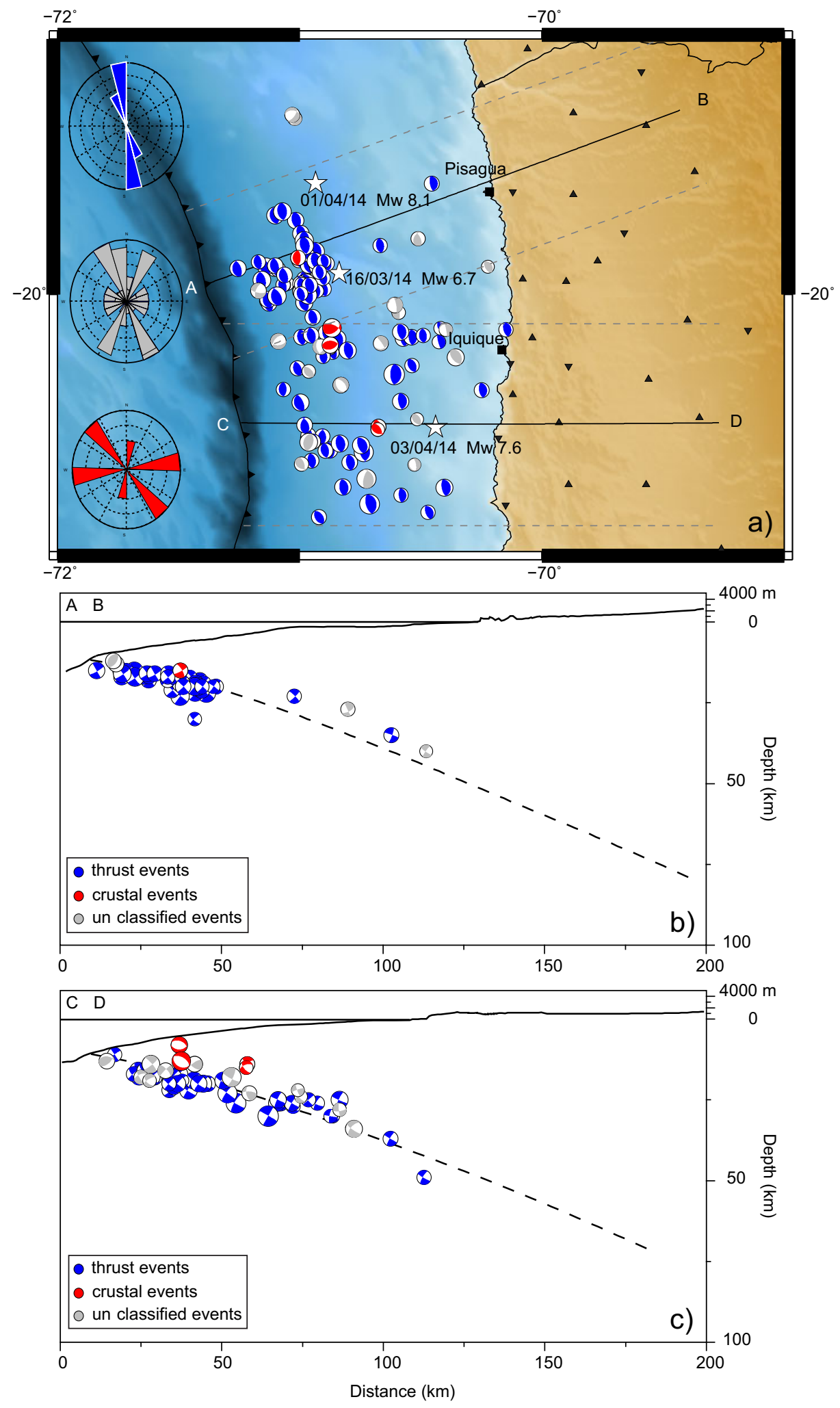


\section{Discussion and conclusions}

The event distribution shown in Fig. 7 presents a clear pattern with respect to the boundaries of the slip distribution of the two largest earthquakes of the Iquique sequence and the low coupling zones identified by Métois et al. (2013) (see Fig. 8 in this document and Fig. 14 on Electronic Supplementary Material). Figure 8 presents the distribution of interplate thrust events and the slip distribution of the Mw 8.1 and Mw 7.6 Iquique earthquakes proposed by Ruiz et al. (2014). In general, the events are distributed to the southwest the rupture zone surrounding the trench-ward boundary of the maximum coseismic slip. A similar situation has been observed in other interplate subduction earthquakes, such as Maule 2010 (Mw 8.8) and Tohoku 2011 (Mw 9.0) (Asano et al. 2011; Agurto et al. 2012), where the larger aftershocks surround the maximum slip of the rupture zone, confirming previous observations of Das and Henry (2003).

The most obvious difference with Maule and Tohoku is that the Iquique foreshocks and aftershocks were concentrated on the shallow interplate interface, westward of the maximum slip area, reaching closer to the trench. We propose that the distribution of foreshocks and aftershocks is not only related to the slip distribution of the mainshock, but it is also related to the rheological conditions and the tectonics of the subduction margin. As we noted earlier, the majority of foreshocks and aftershocks of the 2014 Iquique earthquake (Figs. 6 and 7) are concentrated westward of the main rupture zone, closer to the trench. In the case of Maule $2010 \mathrm{Mw} 8.8$, the number of aftershocks with large magnitude decreased toward the trench in the two segments where the largest slip was located; this can be related to a decrease of effective basal friction below a wide accretionary prism (Moscoso et al. 2011; Cubas et al. 2013; Maksymowicz et al. 2015). In contrast, in the Iquique sequence which is located in an erosive segment of the Chilean margin (Ranero et al. 2006; Contreras Reyes et al. 2012), the largest Mw 4.5 aftershocks are observed in the shallower area of the contact zone. This may be explained by the lack of a large accretionary prism.

If the subducted Nazca Plate, below the accretionary prism, has similar features to those observed seaward

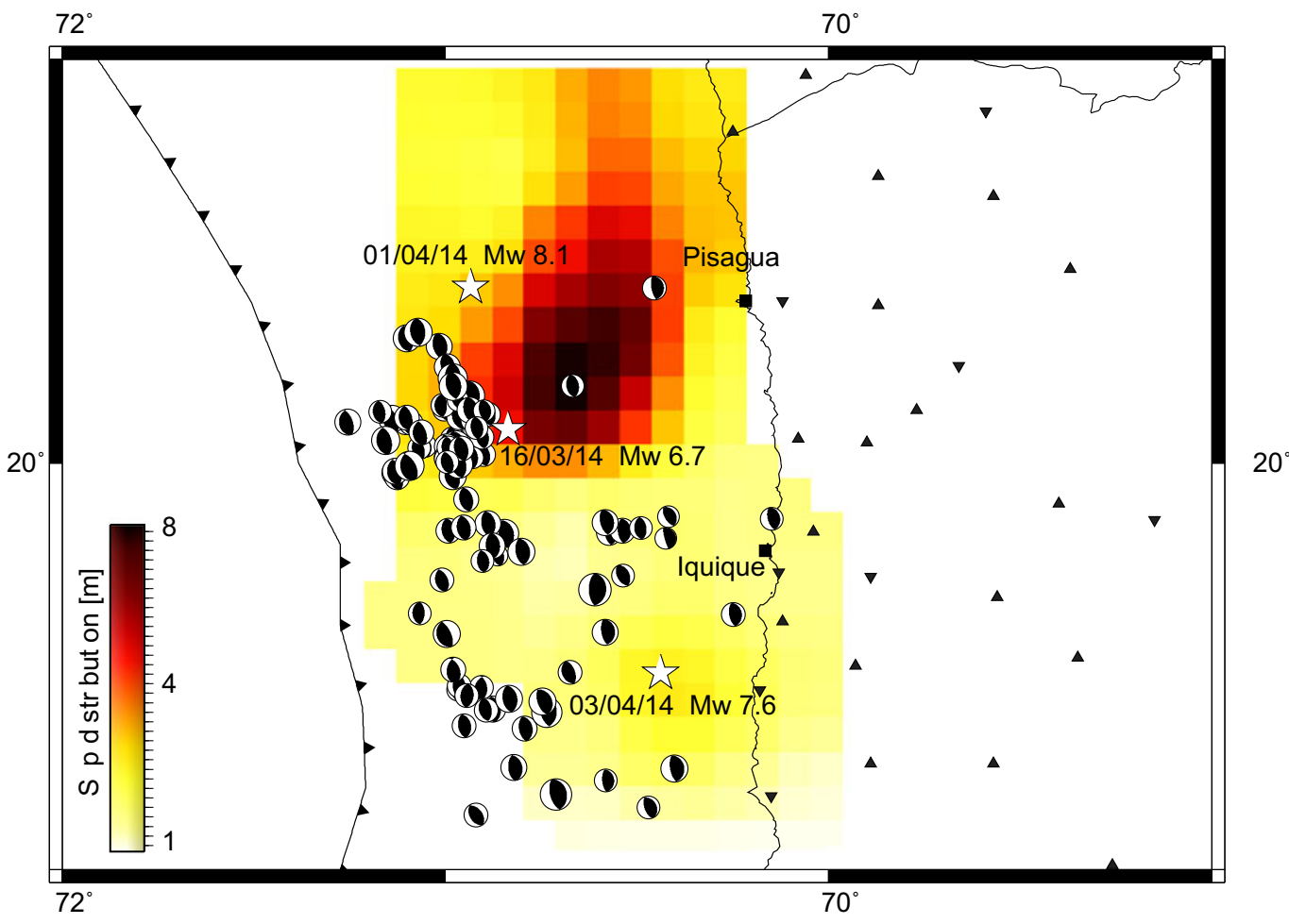

Fig. 8 Map view showing the slip distribution of the Mw 8.1 Iquique earthquake and its largest aftershock of magnitude Mw 7.6 (Ruiz et al. 2014) and the interplate aftershocks from Fig. 9. The stars are the epicenters of the main earthquakes of the Iquique sequence. The aftershocks clearly surround the rupture zone of the mainshock 
from the trench - an irregular bathymetry with horst and graben structures that have more than $2000 \mathrm{~m}$ offset - it is likely that these structures control the location and focal mechanism of events of magnitude larger than $\mathrm{Mw}$ 4.5. Projecting the profile obtained by von Huene and Ranero (2003) to the west of the Mejillones Peninsula, we observe an irregular contact for about $50 \mathrm{~km}$ from the trench to the east (see Fig. 9). After this shallow zone, the number of large magnitude aftershocks decreases, which could be caused by a smoother contact generated by tectonic erosion in the shallow portion of the subducted plate. The strike angles of interplate events are in good agreement with the NW orientation of the horst and graben structures of the subducted Nazca Plate. A similar hypothesis was proposed by Zhan et al. (2012) for the 2011 Tohoku earthquake.

Assuming that the main features of the erosive Northern Chile margin remain similar, we can interpret our results with reference to two marine seismic profiles located in Antofagasta $\left(\sim 22.5^{\circ} \mathrm{S}\right)$ and Tocopilla $\left(\sim 22^{\circ}\right.$
S) (Ranero et al. 2006; Contreras Reyes et al. 2012). This allows us to relate the characteristics of the Iquique sequence with the main features observed in the seismic profiles (see Fig. 9): lack of sediments in the trench, a small frontal accretionary prism, and an eroded continental wedge of about $50 \mathrm{~km}$ width associated to relatively low $\mathrm{P}$ wave velocity that presents pervasive fracturing with high-angle landward-vergent faults. Both foreshocks and aftershocks located here present a strong correlation with the tectonic units of the continental plate. The interplate seismicity stops near the trench where the small frontal accretionary wedge probably inhibits fast seismic ruptures. The shallow interplate seismicity is concentrated below the eroded continental wedge, extending close to $50 \mathrm{~km}$ landward from the trench. In this part of the subduction zone, tectonic erosion at the base of the continental wedge seems to be the first-order deformation process. Furthermore, the transition between the shallow interplate events and the less numerous events located in the deeper contact-as
Fig. 9 Schematic profile of the Northern Chile subduction zone $\left(\sim 20^{\circ} \mathrm{S}\right)$. The diamonds and circles correspond to the computed centroid of the foreshocks and aftershocks with magnitude greater than Mw 45 , respectively. a, b corresponds to profiles $A B$ and $C D$ shown in Fig. 7a. The segmented red line corresponds to our interpretation of the irregularities in the Nazca Plate proposed by von Huene and Ranero (2003). The segmented black line shows our proposition for the seismogenic contact in Northern Chile in comparison with that proposed by Hayes et al. (2012) shown by the gray segmented line. Solid black line, in profiles $\mathrm{AB}$ and $\mathrm{CD}$, represents the estimated in depth rupture of the mainshock and largest aftershock, respectively. Vertical exaggeration $2: 1$

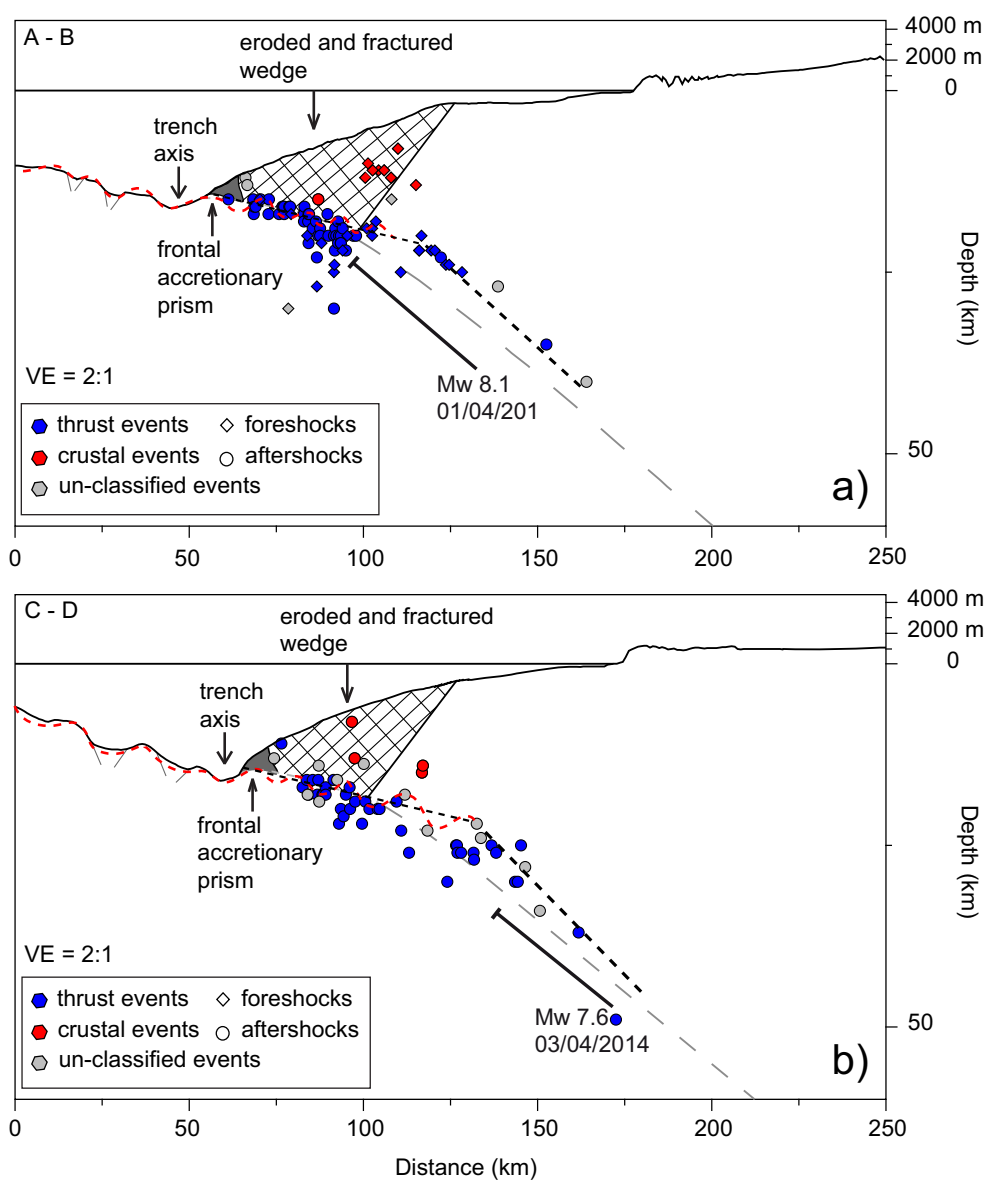


well as the updip limit of the rupture of the mainshockroughly coincides with the landward limit of the eroded wedge, which can be explained by the strong decrease of basal and internal friction due to the fracturing and fluids content in the eroded wedge. Likewise, the crustal events in the upper plate (like the foreshock of March 16) are also located near the landward limit of the eroded wedge. Their high angle reverse fault mechanism suggests that the limit of the eroded wedge can work as a reverse fault and/or that the landward vergent normal faults present in the erosive wedge can be reactivated as reverse faults as the main rupture approaches.

Finally, we observe that the seismogenic contact for South America proposed by Hayes et al. (2012) was used as a reference for this work. There are some problems in the shallower contact zone, similar to those observed in Southern Chile (Maksymowicz et al. 2015). In order to better take into account the distribution of the shallower interplate events, we modified the seismogenic contact in Fig. 9 and propose that in the shallower zone, the dip angle is close to $10^{\circ}$, compared with the value between $15^{\circ}$ and $20^{\circ}$ of the slab 1.0 model of Hayes et al. (2012). This is similar to what was observed by Contreras Reyes et al. (2012) in the seismic profile at $22^{\circ} \mathrm{S}$. On the other hand, the angle of the deeper interplate contact events shows a subduction angle in good agreement with the values from Hayes et al. (2012) and Contreras Reyes et al. (2012). The abrupt change in the subduction dip angle suggests very strong slab bending forces in this zone.

In summary, we computed the location and moment tensor of 151 foreshocks and aftershocks of the Iquique 2014 earthquake. The analyzed events are concentrated in a band of about $50 \mathrm{~km}$ to the east from the trench. The obtained solutions for the moment tensor showed a very good adjustment for most of the waveforms giving us better constrained depths which are critical for a correct interpretation of the tectonic structures observed in the scope area. Moreover, the fault plane solutions for the aftershocks present a better fit than that obtained for the foreshocks, showing the importance of having a dense local network to compute the regional moment tensor.

We propose that the distribution of the observed seismicity may be controlled by the irregularities in the contact between the subduting Nazca Plate and South American plate. This behavior, with a large diversity of events, is apparently a common characteristic for erosive margins due to the lack of sediments. In contrast, the accretionary margins add fluids and sediments to the subducting plate filling the heterogeneities and creating a "smoother" interplate contact that could generate less diversity of earthquakes. Furthermore, an important number of crustal events in the South American plate are a sign of the complexities related with the subduction process in Northern Chile and how the extreme erosive margin in that area affect the overriding plate creating fractured zones with the capacity of potentially generating a large tsunamigenic earthquake. Finally, we propose the presence of a slab bending that could be responsible of the abrupt change in the dip angle of the seismogenic contact.

Acknowledgments We thank the support of the Chilean Nation al Science Foundation project FONDECYT No. 11130230 and Programa Riesgo Sísmico (AIN, Universidad de Chile). A.M was supported by project FONDECYT 3150160. We thank Centro Sismológico Nacional (www.sismologia.cl) and IPOC consortium for making raw data available to us.

\section{References}

Agurto H, Rietbrock A, Ryder I, Miller M (2012) Seismic afterslip characterization of the 2010 MW 8.8 Maule, Chile, earth quake based on moment tensor inversion. Geophys Res Lett 39, L20303. doi: 10.1029/2012GL053434.

Asano Y, Saito T, Ito Y, Shiomi K, Hirose H, Takumi M, Aoi S, Hori S, Sekiguchi S (2011) Spatial distribution and focal mechanisms of aftershocks of the 2011 off the Pacific coast of Tohoku Earthquake. Earth, Planets Space 63:669 673. doi:10.5047/eps.2011.06.016

Béjar Pizarro M, Socquet A, Armijo R, Carrizo D, Genrich J, Simons M (2013) Andean structural control on interseismic coupling in the North Chile subduction zone. Nat Geosci 6: 462 467. doi:10.1038/ngeo 1802

Comte D, Pardo M (1991) Reappraisal of great historical earth quakes in the northern Chile and southern Peru seismic gaps. Nat Hazards 4:23 44. doi:10.1007/BF00126557

Contreras Reyes E, Jara J, Grevemeyer I, Ruiz S, Carrizo D (2012) Abrupt change in the dip of the subducting plate beneath north Chile. Nat Geosci 5:342 345. doi:10.1038/ngeo 1447

Cubas N, Avouac JP, Souloumiac P, Leroy Y (2013) Megathrust friction determined from mechanical analysis of the forearc in the Maule earthquake area. Earth Planet Sci 381:92 103. doi: 10.1016/j.epsl.2013.07.037

Das S, Henry C (2003) Spatial relation between main earthquake slip and its aftershock distribution. Rev Geophys 41:1013. doi:10.1029/2002RG000119

Engdahl R, Villaseñor A (2002) Global seismicity: 1900 1999. In: International Handbook of Earthquake and Engineering Seismology. Part A. Academic Press, California, pp 665690

Fuenzalida A, Schurr B, Lancieri M, Sobiesiak M, Madariaga R (2013) High resolution relocation and mechanism of after shocks of the 2007 Tocopilla (Chile) earthquake. Geophys J Int 194:1216 1238. doi:10.1093/gji/ggt163 
Gardi A, Lemoine A, Madariaga R, Campos J (2006) Modeling of stress transfer in the Coquimbo region of central Chile. J Geophys Res 111:B04307. doi:10.1029/2004JB003440

Hayes GP, Wald DJ, Johnson RL (2012) Slab1.0: a three-dimen sional model of global subduction zone geometries. J Geophys Res 117:B01302. doi:10.1029/2011JB008524

Hayes GP, Herman MW, Barnhart WD, Furlong KP, Riquelme S, Benz HM, Bergman E, Barrientos S, Earle PS, Samsonov S (2014) Continuing megathrust earthquake potential in Chile after the 2014 Iquique earthquake. Nature 512:295 298. doi: 10.1038 /nature 13677

Herrmann RB (2013) Computer programs in seismology: an evolving tool for instruction and research. Seismol Res Lett 84:1081 1088. doi:10.1785/0220110096

Hubbard J, Barbot S, Hill EM, Tapponnier P (2015) Coseismic slip on shallow décollement megathrusts: implications for seis mic and tsunami hazard. Earth Sci Rev 141:45 55. doi:10. 1016/j.earscirev.2014.11.003

Husen S, Kissling E, Flueh E, Asch G (1999) Accurate hypocenter determination in the seismogenic zone of the subducting Nazca plate in north Chile using a combined on /offshore network. Geophys J Int 138:687 701. doi:10.1046/j.1365 246x.1999.00893.x

Kato A, Nakagawa S (2014) Multiple slow slip events during a foreshock sequence of the 2014 Iquique, Chile $\mathrm{M}_{\mathrm{w}} 8.1$ earth quake. Geophys Res Lett 41:5420 5427. doi:10.1002/ 2014GL061138

Kausel E (1986) Los terremotos de agosto de 1868 y mayo de 1877 que afectaron el sur del Perú y norte de Chile. Boletín Academia Chilena Ciencias 3:8 14

Kelleher J (1972) Rupture zones of large South American earth quakes and some predictions. J Geophys Res 77:2087 2103. doi:10.1029/JB077i011p02087

Lay T, Kanamori H, Ammon CJ, Koper KD, Hutko AR, Ye L, Yue H, Rushing TM (2012) Depth varying rupture properties of subduction zone megathrust faults. J Geophys Res 117: B04311. doi:10.1029/2011JB009133

Lay T, Yue H, Brodsky EE, An C (2014) The April 1, 2014 Iquique, Chile $\mathrm{Mw} 8.1$ earthquake rupture sequence. Geophys Res Lett 41:3818 3825. doi:10.1002/ 2014GL060238

Lomax A, Virieux J, Volant P, Berge Thierry C (2000) Probabilistic earthquake location in $3 \mathrm{D}$ and layered models. In: Advances in seismic event location. Springer, Netherlands, pp 101 134. doi:10.1007/978940159536 0_

Maksymowicz A, Trehu A, Contreras Reyes E, Ruiz S (2015) Density depth model of the continental wedge at the maxi mum slip segment of the Maule Mw8.8 megathrust earth quake. Earth Planet Sci 409:265 277. doi:10.1016/j.epsl. 2014.11.005

Malgrange M, Madariaga R (1983) Complex distribution of large thrust and normal fault earthquakes in the Chilean subduction zone. Geophys J Int 73:489 505. doi:10.1111/j.1365 246X. 1983.tb03326.x

McCann WR, Nishenko SP, Sykes LR, Krause J (1979) Seismic gaps and plate tectonics: seismic potential for major bound aries. In Earth Prediction Seismicity Patterns 117:1082 1147. doi:10.1007/978 30348643052

Meng L, Huang H, Bürgmann R, Ampuero JP, Strader A (2015) Dual megathrust slip behaviors of the 2014 Iquique earthquake sequence. Earth Planet Sci Lett 411:177 187. doi:10.1016/j.epsl.2014.11.041

Montessus de Ballore F (1912) Historia sísmica de los Andes meridionales al sur del paralelo XVI. Imprenta Cervantes, Santiago, pp 545591

Métois M, Socquet A, Vigny C, Carrizo D, Peyrat S, Delorme A, Maureira E, Valderas Bermejo M, Ortega I (2013) Revisiting the North Chile seismic gap segmentation using GPS derived interseismic coupling. Geophys J Int 194:1283 1294. doi:10. 1093/gij/ggt183

Moscoso E, Grevemeyer I, Contreras Reyes E, Flueh ER, Dzierma Y, Rabbel W, Thorwart M (2011) Revealing the deep struc ture and rupture plane of the 2010 Maule, Chile Earthquake $(\mathrm{Mw}=8.8)$ using wide angle seismic data. Earth Planet Sci 307:147 155

Nishenko SP (1985) Seismic potential for large and great interplate earthquakes along the Chilean and southern Peruvian mar gins of South America: a quantitative reappraisal. J Geophys Res 90:3589 3615. doi:10.1029/JB090iB05p03589

Pacheco J, Sykes LR (1992) Seismic moment catalog of large shallow earthquakes, 1900 to 1989. Bull Seismol Soc Am 82: 13061349

Peyrat S, Campos J, De Chabalier JB, Perez A, Bonvalot S, Bouin MP, Legrand D, Nercessian A, Charade O, Patau G, Clévédé E, Kausel E, Bernard P, Vilotte JP (2006) Tarapacá interme diate-depth earthquake ( $\mathrm{Mw} 7.7,2005$, northern Chile): a slab-pull event with horizontal fault plane constrained from seismologic and geodetic observations. Geophys Res Lett 33: 22. doi:10.1029/2006GL027710

Peyrat S, Madariaga R, Buforn E, Campos J, Asch G, Vilotte JP (2010) Kinematic rupture process of the 2007 Tocopilla earthquake and its main aftershocks from teleseismic and strong motion data. Geophys J Int 182:1411 1430. doi:10. 1111/j.1365 246X.2010.04685.x

Ranero C, von Huene R, Weinrebe W, Reichert C (2006) Tectonic processes along the Chile convergent margin. In: The Andes. Springer, Berlin, pp 91 121. doi:10.1007/978 354048684 85

Ruegg JC, Campos J, Armijo R, Barrientos S, Briole P, Thiele R, Arancibia M, Canuta J, Duquesnoy T, Chang M (1996) The $\mathrm{Mw}=8.1$ Antofagasta (North Chile) earthquake of July 30, 1995: first results from teleseismic and geodetic data. Geophys Res Lett 23:917 920. doi:10.1029/96GL01026

Ruiz S, Metois M, Fuenzalida A, Ruiz J, Leyton F, Grandin R, Vigny C, Madariaga R, Campos J (2014) Intense foreshocks and a slow slip event preceded the 2014 Iquique Mw 8.1 earthquake. Science 345:1165 1169. doi:10.1126/science. 1256074

Scholz CH (1998) Earthquakes and friction laws. Nature 391:37 42. doi: $10.1038 / 34097$

Schurr B, Asch G, Hainzl S, Bedford J, Hoechner A, Palo M, Wang R, Moreno M, Bartsch M, Zhang Y (2014) Gradual unlocking of plate boundary controlled initiation of the 2014 Iquique earthquake. Nature 512:299 302. doi:10.1038/ nature 13681

Urrutia R, Lanza C (1993) Catástrofes en Chile 1541 1992. La Noria, Santiago of Chile, pp 3031

von Huene R, Culotta R (1989) Tectonic erosion at the front of the Japan Trench convergent margin. Tectonophysics 160:75 90. doi:10.1016/0040 1951(89)90385 5 
von Huene R, Ranero C (2003) Subduction erosion and basal friction along the sediment starved convergent margin off Antofagasta. Chile J Geophys Res 108:2079. doi:10.1029/ 2001JB001569

Yagi Y, Okuwaki R, Enescu B, Hirano S, Yamagami Y, Endo S, Komoro T (2014) Rupture process of the 2014 Iquique Chile earthquake in relation with the foreshock activity. Geophys Res Lett 41(12):4201 4206. doi:10.1002/2014GL060274
Zhan Z, Helmberger D, Simons M, Kanamori H, Wu W, Cubas N, Duputel Z, Chu R, Tsai V, Avouac J (2012) Anomalously steep dips of earthquakes in the 2011 Tohoku Oki source region and possible explanations. Earth Planet Sci 353:121 133. doi:10.1016/j.epsl.2012. 07.038 
Karlsruher Institut für Technologie

\section{Repository KITopen}

Dies ist ein Postprint/begutachtetes Manuskript.

\section{Empfohlene Zitierung:}

León-Ríos, S.; Ruiz, S.; Maksymowicz, A.; Leyton, F.; Fuenzalida, A.; Madariaga, R.

Diversity of the 2014 lquique's foreshocks and aftershocks: clues about the complex rupture process of a Mw 8.1 earthquake.

2016. Journal of seismology, 20

doi:10.5445/IR/1000086917

Zitierung der Originalveröffentlichung:

León-Ríos, S.; Ruiz, S.; Maksymowicz, A.; Leyton, F.; Fuenzalida, A.; Madariaga, R.

Diversity of the 2014 lquique's foreshocks and aftershocks: clues about the complex rupture process of a Mw 8.1 earthquake.

2016. Journal of seismology, 20 (4), 1059-1073. doi:10.1007/s10950-016-9568-6 